\title{
JARINGAN SARAF TIRUAN BACKPROPAGATION UNTUK PREDIKSI CURAH HUJAN DI WILAYAH KABUPATEN WONOSOBO
}

\author{
Ghufron Zaida Muflih ${ }^{1}$, Sunardi ${ }^{2}$, Anton Yudhana ${ }^{3}$ \\ 1, 2, ${ }^{3}$ Universitas Ahmad Dahlan, Yogyakarta \\ Ghufron1807048002@webmail.uad.ac.id ${ }^{1}$, sunardi@mti.uad.ac.id ${ }^{2}$, \\ eyudhana@mti.uad.ac.id ${ }^{3}$
}

\begin{abstract}
ABSTRAK
Curah hujan merupakan gejala alam dan banyak bergantung dari banyak faktor serta menjadi bagian yang sangat penting bagi kehidupan di bumi. Air hujan merupakan sumber daya yang banyak dimanfaatkan oleh manusia. Keadaan iklim yang tidak menentu menyebabkan curah hujan menuju ke arah (trend) meningkat atau menurun. Jaringan saraf tiruan merupakan algoritma yang secara umum sangat baik dalam permasalahan pengenalan pola, bekerja dengan menirukan jaringan saraf manusia yang dapat menyimpan informasi-informasi dan membentuk sebuah tujuan dari sistem saraf tersebut. Penggunaan jaringan saraf tiruan sebagai prediksi curah hujan di wilayah Kabupaten Wonosobo menggunakan metode backpropagation untuk mengukur tingkat curah hujan yang turun dalam kurun waktu tertentu, menggunakan data curah hujan stasiun 24 Wanganaji tahun 2009-2011 sebagai pelatihan dan pengujian. Arsitektur jaringan saraf yang digunakan adalah 12-10-1, terdiri dari 12 nilai masukan data curah hujan 12 bulan, 10 neuron hidden layer dan 1 nilai keluaran data curah hujan bulan berikutnya, MSE yang diperoleh pada pelatihan 0.00099899 dicapai pada epoch yang ke 161, dengan koefisien koerelasi R yang dihasilkan sebesar 0.99205, MSE pada pengujian jaringan diperoleh dengan nilai 0.17042.
\end{abstract}

Kata kunci: backpropagation, curah hujan, jaringan saraf tiruan

\begin{abstract}
Rainfall is a natural symptom and many depend on many factors and become a very important part of life on Earth. Rainwater is a resource that is widely utilized by humans. The uncertain climatic conditions cause the rainfall to lead to an increased or decreased trend. A synthetic neural network is a generally excellent algorithm in pattern recognition problems, working by imitating a human neural network that can store information and form a goal of the nervous system. Use of artificial neural network as a prediction of rainfall in Wonosobo Regency uses the backpropagation method to measure the rate of rainfall that falls for a certain period, using rainfall data of 24 Wanganaji station in 2009-2011 as training and testing. The neural network
\end{abstract}




\section{Ghufron Zaida Muflih, Sunardi, Anton Yudhana}

architecture used is 12-10-1, consisting of 12 values of 12-month rainfall data input, 10 neurons hidden layers and 1 of the subsequent rainfall data output value of the month, MSE obtained in training 0.00099899 achieved in the epoch to 161 , with a coefficients of R-generated coefficient of 0.99205 , MSE on tissue testing obtained with a value of 0.17042 .

Keywords: backpropagation, rainfall, artificial neural networks

\section{PENDAHULUAN}

Hujan berperan penting bagi kehidupan, curah hujan yang turun pada suatu wilayah dapat diprediksi namun tidak dapat ditentukan secara pasti, menggunakan data historis masa lampau untuk memprediksi besarnya curah hujan yang akan datang. Kriteria intensitas curah hujan di wilayah Indonesia antara lain ringan dengan curah hujan 1-5mm/jam, kategori sedang dengan curah hujan 5$10 \mathrm{~mm} / \mathrm{jam}$, kategori lebat 10-20mm/jam dan kategori sangat lebat dengan curah hujan >20mm/jam(BMKG, 2010). Beberapa akibat jika curah hujan pada suatu wilayah dengan intensitas tinggi seperti banjir dan tanah longsor, serta bencana kekeringan karena intensitas hujan pada suatu wilayah sangat rendah.

Kabupaten Wonosobo merupakan wilayah dataran tinggi yang berada pada rentang $250 \mathrm{dpl}$ - $2250 \mathrm{dpl}$ dengan dominasi pada rentang $500 \mathrm{dpl}$ - $1000 \mathrm{dpl} 50 \%$ dari seluruh areal, dengan luas wilayah 98.468 hektar. Keadaan topografi berupa perbukitan dan pegunungan $56.37 \%$ kemiringan lereng antara $15-40 \%$, kondisi klimatologi secara umum beriklim tropis dengan dua musim, hampir sepanjang tahun terjadi hujan dan hanya bulan september tidak terjadi hujan sama sekali, dengan kisaran curah hujan $1.660-4.049 \mathrm{~mm} / \mathrm{th}$, suhu udara rata-rata harian 14,3 $-26,5{ }^{\circ} \mathrm{C}$. Dengan kondisi tersebut sektor pertanian sangat dominan dalam perekonomian (Wonosobokab.go.id, 2014a). Curah hujan juga berpengaruh terhadap beberapa sektor meliputi pertanian, industri dan perdagangan. Banyak produk pertanian dan perkebunan di wilayah Wonosobo seperti kentang, ubi kayu, carica, teh, jagung dan tanaman pokok lain. Pada bidang industri seperti usaha batik, pengolahan tanaman pangan, usaha alat pertanian, serta produk lain di sektor kehutanan, pembangkit listrik mikro hidro, perikanan dan peternakan, sedangkan perdagangan pada nilai ekspor non migas yang berasal dari kabupaten Wonosobo dengan pertumbuhan ekonomi yang terus meningkat dari tahun 2009 
2011 (Wonosobokab.go.id, 2014b). Pengamatan terhadap kondisi cuaca menjadi penting untuk menunjang berbagai kegiatan tersebut terutama curah hujan, sehingga dapat dimanfaatkan oleh pihak-pihak yang membutuhkan.

Curah hujan merupakan jumlah air hujan yang turun pada daerah tertentu dalam waktu tertentu, diukur dalam harian, bulanan dan tahunan dalam skala milimeter atau sentimeter serta dipengaruhi beberapa faktor antara lain, topografi, arah lereng medan, arah angin, serta kecepatan angin (Mukid \& Sugito, 2013). Intensitas curah hujan dapat menjadi dasar dalam memperkirakan dampak hujan seperti bencana banjir, tanah longsor dan kekeringan. Selain bencana prediksi curah hujan juga bisa dimanfaatkan pada bidang pertanian, industri serta perdagangan atau perekonomian untuk mengambil langkah-langkah atau kebijakan terkait. Metode ststistik untuk peramalan masih banyak digunakan hingga saat ini seperti simple regression analysis, decomposition, exponential smoothing, autoregressie integrated moving average (ARIMA) dan seasonal autoregressive integrated moving average (SARIMA) (Haviluddin, Arifin, Kridalaksana, \& Cahyadi, 2016).

Beberapa penelitian yang menggunakan jaringan saraf tiruan salah satunya adalahpenerapan algoritma backpropagation serta menentukan tingkat akurasi berdasarkan MSE untuk memprediksi curah hujan harian (Dewi, Bahri, \& Irwansyah, 2015). Penelitian lain, membuat sistem yang dapat melakukan peramalan dengan metode jaringan saraf tiruan backpropagation dengan Artificial Bee Colony untuk mengetahui tingkat kesalahan dari permasalahan curah hujan (Pradnyana, Soebroto, \& Perdana, 2018). Penelitian selanjutnya menjelaskan proses prediksi curah hujan berdasarkan data sebelumnya serta diterapkan metode backpropagation untuk memprediksi curah hujan serta menguji curah hujan secara manual (Manalu, 2016), selanjutnya melakukan analisa data cuaca menggunakan algoritma jaringan saraf tiruan dengan menggunakan 14 variabel, dengan tujuan menyediakan informasi cuaca yang akurat sehingga dapat memberikan informasi sedini mungkin kepada pihak yang membutuhkan dalam penanganan permasalahan banjir (Yunita, 2015), pembangunan model jaringan saraf tiruan propagasi balik dengan data masukan parameter cuaca seperti suhu, 
kelembaban udara, tekanan udara dan penguapan serta outputnya prediksi curah hujan, pembangunan model pada 3 skala waktu, bulanan, dasarian dan harian dengan konfigurasi yang berbeda pada setiap skala waktu untuk memaksimalkan kemampuan model (Rachmawati, 2015).

Pada penelitian ini menerapkan model dari algoritma backpropagation sebagai prediksi curah hujan bulanan di wilayah kabupaten Wonosobo untuk membantu memberikan informasi data curah hujan sebagai antisipasi terhadap bencana, menyediakan data curah hujan untuk wilayah yang tidak memiliki stasiun pengamatan atau alat pengukur curah serta pemanfaatan pada bidang pertanian dan industri atau bidang lain yang membutuhkan.

\section{METODE PENELITIAN}

Pada penelitian ini data yang digunakan berupa data sekunder dari Badan Meteorologi, Klimatologi dan Geofisika (BMKG) stasiun pengamatan Wanganaji Wonosobo mulai tahun 2009 sampai dengan 2011. Dalam melakukan pelatihan dan pengolahan data jumlah curah hujan, perangkat lunak yang digunakan dalam pengujian data dan proses penentuan jumlah curah hujan pada bulan berikutnya adalah perangkat lunak Matlab R2018a.

Perancangan arsitektur jaringan saraf tiruan yang disusun sedemikian rupa sesuai dengan algoritma pembelajaran yang dipilih, menggunakan algoritma pembelajaran backpropagation dengan model jaringan yang terdiri dari lapisan masukan atau input layer, lapisan tersembunyi atau hidden layer dan keluaran atau output layer. Desain jaringan saraf tiruan ditunjukkan pada Gambar 1.

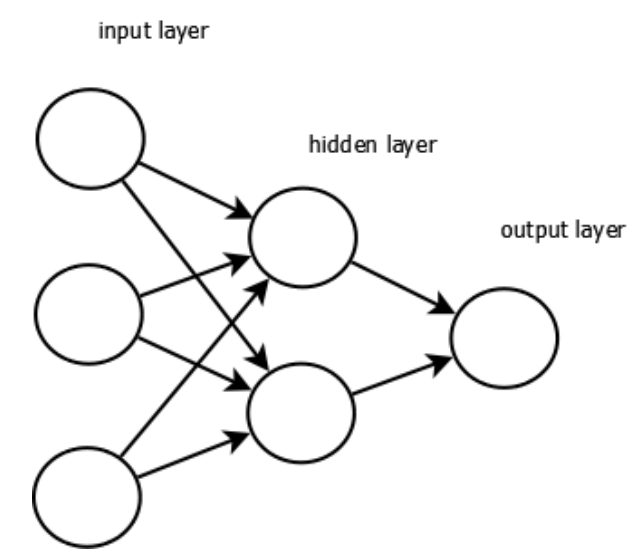

Gambar 1. Desain Jaringan Saraf Tiruan Backpropagation 
Metode jaringan saraf tiruan backpropagation, merupakan algoritma pembelajaran untuk memperkecil tingkat error dengan cara menyesuaikan bobotnya berdasarkan perbedaan output dan target yang akan dicapai. Arsitektur backpropagation terdiri dari tiga layer dalam proses pembelajarannya, yaitu input layer, hidden layer dan output layer (Sutawinaya, Astawa, \& Hariyanti, 2017). Metode pelatihan jaringan saraf tiruan backpropagation merupakan pelatihan yang terawasi dan dilakukan dengan mengubah parameter-parameter fungsi pelatihan sehingga diperoleh parameter jaringan yang mampu mengoptimalkan kerja jaringan (Oktavianingsih, Muliadi, \& Apriyansyah, 2018), Pelatihan backpropagation meliputi dua fase (Manalu, 2016), yaitu:

1. Fase pertama, fase maju dengan menghitung pola maju mulai dari input layer hingga hidden layer menggunakan aktivasi yang ditentukan.

2. Fase kedua, fase mundur dimana selisih keluaran dengan target yang di inginkan merupakan kesalahan yang terjadi, kesalahan di propagasi mundur dari garis yang berhubungan langsung dengan unit unit dilayar keluaran.

Rancangan penelitian terdiri dari beberapa tahapan, yaitu studi literatur, pengumpulan data, metode JST backpropagation, pelatihan jaringan, dan pengujian. Alir penelitian seperti pada Gambar 2.

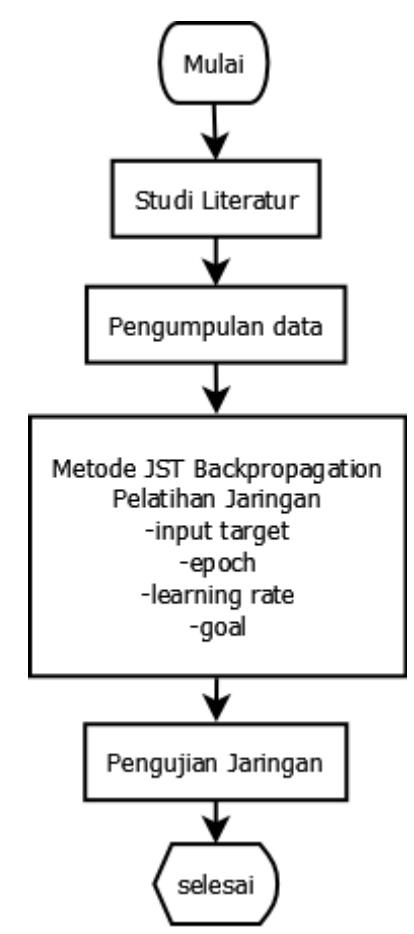

Gambar 2.Diagram Alir Penelitian 
Persiapan awal penelitian dengan mengambil data curah hujan dan persiapan perangkat lunak untuk pengolahan data, serta untuk meningkatkan keakuratan dari hasil penelitian dengan mencari literatur untuk mempelajari penelitian terkait yang dapat dijadikan acuan sebagai landasan penelitian. Data yang digunakan sebagai masukan adalah data curah hujan dari tahun 2009 sampai 2011, variabel tersebut digunakan untuk pelatihan pada jaringan dan juga sebagai data uji.

Langkah pembelajaran sebagai berikut:

Langkah 0. Inisiasi bobot (tetapkan dengan nilai acak kecil)

Langkah 1. Selama syarat kondisi false kerjakan langkah 2-9

Langkah 2. Untuk setiap pasangan yang akan dilakukan pembelajaran, kerjakan langkah 3-8

Fase maju

Langkah 3. Setiap unit input $(x i, i=1,1, \ldots, n)$ menerima sinyal dan meneruskan sinyal ke semua unit pada lapisan tesembunyi

Langkah 4. Setiap unit tersembunyi (zj, j=1,2,..,p) menjumlahkan bobot sinyal input dengan persamaan berikut:

$$
z_{-} i n_{j}=v_{o j}+\sum_{i=1}^{n} x_{i} v_{i j}
$$

Hitung sinyal output dengan fungsi aktivasinya

$$
z_{j}=f\left(z_{-} i n_{j}\right)
$$

Kirimkan sinyal ini ke semua unit pada lapisan output.

Langkah 5. Setiap unit output (yk, $\mathrm{k}=1,2, \ldots \mathrm{m}$ ) menjumlahkan input terbobotnya

$$
z_{-} i n_{j}=v_{o j}+\sum_{i=1}^{n} x_{i} v_{i j}
$$

Hitung sinyal output dengan fungsi aktivasinya

$$
y_{k}=\left(t_{k}-y_{k}\right) f^{\prime}\left(y_{-} i n_{k}\right)
$$

Fase mundur

Langkah 6. Setiap unit output (yk, $\mathrm{k}=1, \ldots, \mathrm{m})$ menerima pola target sesuai dengan pola input pelatihan, kemudian hitung error seperti persamaan

$$
\delta_{k}=\left(t_{k}-y_{k}\right) f^{\prime}\left(y_{-} i n_{k}\right)
$$

Hitung suku koreksi bobot (digunakan untuk perbaruan wjk),

$$
\Delta w_{j k}=\alpha \delta_{k} z_{j}
$$

Hitung suku koreksi bias (digunakan untuk perbaruan wok),

$$
\Delta w_{o k}=\delta \alpha_{k}
$$

Kirimkan $6 \mathrm{k}$ ke unit-unit dilapis bawahnya

Langkah 7. Setiap unit tersembunyi $(z j, j=1, . ., p)$ menjumlahkan delta inputnya (dari unit-unit yang berada pada lapis diatasnya)

$$
\delta_{-} i n_{j}=\sum_{k=1}^{m} \delta k w_{j k}
$$


Hitung suku informasi error,

$$
\delta_{j}=\delta_{-} n_{j} f^{\prime}\left(z_{-} i n_{j}\right)
$$

Hitung suku koreksi bobot (untuk perbaruan vij)

$$
\Delta v_{i j}=\alpha \delta_{j} x_{i}
$$

Hitung suku koreksi bias (untuk perbaruan voj),

$$
\Delta v_{o j}=\alpha \delta_{j}
$$

Perbaruan bobot dan bias

Langkah 7. Setiap unit output (yk, $\mathrm{k}=1, . ., \mathrm{m})$ perbarui bobot-bobot dan biasnya:

$$
w_{j k}(\text { baru })=w_{j k}(\text { lama })+\Delta w_{j k}
$$

Langkah 8. Setiap unit tersembunyi $(z j, j=1, \ldots, p)$ perbarui bobot-bobot dan biasnya $(\mathrm{i}=0, \ldots, \mathrm{n})$ :

$$
v_{i j}(\text { baru })=v_{i j}(\operatorname{lama})+\Delta v_{i j}(13)
$$

Langkah 9. Uji syarat berhenti

- Fungsi aktivasi sigmoid

$$
\begin{aligned}
& f(x)=\frac{1}{1+e^{-x}} \\
& f^{\prime}(x)=f(x)[1-f(x)]
\end{aligned}
$$

\section{HASIL PENELITIAN DAN PEMBAHASAN}

\begin{tabular}{|c|c|c|c|c|c|c|c|c|c|c|c|c|c|}
\hline Tahun & Januari & \begin{tabular}{l|l} 
Pebruari \\
\end{tabular} & Maret & April & Mei & Juni & Juli & Agustus & September & Oktober & \begin{tabular}{|l|l|} 
Nopember & Desember \\
\end{tabular} & \multicolumn{2}{|l|}{ Tahunan } \\
\hline & & & & & & & & & & & & Total (mm/thn) & $\mathrm{R}_{24}$ \\
\hline 2009 & 67 & 737 & 769 & 277 & 85 & 178 & 8 & 0 & 21 & 285 & 620 & 901 & 224 \\
\hline 2010 & 903 & 741 & 919 & 944 & 630 & 315 & 236 & 548 & 519 & 612 & 516 & 7317 & 293 \\
\hline 2011 & 203 & 308 & 605 & 691 & 0 & 106 & 73 & 20 & 8 & 96 & 516 & 3407 & 172 \\
\hline
\end{tabular}

Dalam penelitian memprediksi curah hujan bulanan di wilayah kabupaten Wonosobo, data yang digunakan sebagai pelatihan dan pengujian adalah data curah hujan selama tiga tahun, yaitu tahun 2009-2011, sumber data berasal dari stasiun pengamatan Wanganaji Kabupaten Wonosobo. Data curah hujan selama

\begin{tabular}{|c|c|c|c|c|c|c|c|c|c|c|c|c|}
\hline tahun & jan & feb & mar & apr & may & jun & jul & aug & sep & oct & nov & dec \\
\hline 2009 & 0.7321 & 0.7912 & 0.8212 & 0.3598 & 0.9 & 0.2669 & 0.1075 & 0.1 & 0.1197 & 0.3673 & 0.6815 & 0.5492 \\
\hline 2010 & 0.8537 & 0.6706 & 0.8718 & 0.9 & 0.5452 & 0.1893 & 0.1 & 0.4525 & 0.4198 & 0.5249 & 0.4164 & 0.3237 \\
\hline 2011 & 0.3079 & 0.4155 & 0.7197 & 0.8078 & 0.1 & 0.2086 & 0.1748 & 0.1205 & 0.1082 & 0.1983 & 0.6286 & 0.9 \\
\hline
\end{tabular}
tiga tahun diberikan pada Tabel 1.

Tabel 1. Data Curah Hujan Selama 3 Tahun

Sumber: bps jateng.go.id

Data curah hujan setelah di normalisasi terlihat pada Tabel 2.

Tabel 2. Data Curah Hujan Setelah Normalisasi

Data yang digunakan untuk pelatihan jaringan menggunakan data curah hujan pada bulan ke 1 hingga bulan ke 24, sedangkan untuk pengujian jaringan menggunakan data curah hujan pada bulan ke 13 sampai dengan bulan ke 36 . 


\section{Ghufron Zaida Muflih, Sunardi, Anton Yudhana}

Tabel 3. Data Pelatihan Jaringan

\begin{tabular}{|c|c|c|c|c|c|c|c|c|c|c|c|c|c|}
\hline \multirow{2}{*}{ pola } & \multirow[b]{2}{*}{$\mathrm{x} 1$} & & & & & & & & & & & & \\
\hline & & $x 2$ & $x 3$ & $x 4$ & $\times 5$ & $x 6$ & $x 7$ & $x 8$ & $\times 9$ & $x 10$ & x11 & $x 12$ & target \\
\hline 1 & 0.7321 & 0.7912 & 0.8212 & 0.3598 & 0.9 & 0.2669 & 0.1075 & 0.1 & 0.1197 & 0.3673 & 0.6815 & 0.5492 & 0.8537 \\
\hline 2 & 0.7912 & 0.8212 & 0.3598 & 0.9 & 0.2669 & 0.1075 & 0.1 & 0.1197 & 0.3673 & 0.6815 & 0.5492 & 0.8537 & 0.6706 \\
\hline 3 & 0.8212 & 0.3598 & 0.9 & 0.2669 & 0.1075 & 0.1 & 0.1197 & 0.3673 & 0.6815 & 0.5492 & 0.8537 & 0.6706 & 0.8718 \\
\hline 4 & 0.3598 & 0.9 & 0.2669 & 0.1075 & 0.1 & 0.1197 & 0.3673 & 0.6815 & 0.5492 & 0.8537 & 0.6706 & 0.8718 & 0.9 \\
\hline 5 & 0.9 & 0.2669 & 0.1075 & 0.1 & 0.1197 & 0.3673 & 0.6815 & 0.5492 & 0.8537 & 0.6706 & 0.8718 & 0.9 & 0.5452 \\
\hline 6 & 0.2669 & 0.1075 & 0.1 & 0.1197 & 0.3673 & 0.6815 & 0.5492 & 0.8537 & 0.6706 & 8718 & 0.9 & 0.5452 & 1893 \\
\hline 7 & 0.1075 & 0.1 & 0.1197 & 0.3673 & 0.6815 & 0.5492 & 0.8537 & 0.6706 & 0.8718 & 0.9 & 0.5452 & 0.1893 & 0.1 \\
\hline 8 & 0.1 & 0.1197 & 0.3673 & 0.6815 & 0.5492 & 0.8537 & 0.6706 & 0.8718 & 0.9 & 0.5452 & 0.1893 & 0.1 & 0.4525 \\
\hline 9 & 0.1197 & 0.3673 & 0.6815 & 0.5492 & 0.8537 & 0.6706 & 0.8718 & 0.9 & 0.5452 & 0.1893 & 0.1 & 0.4525 & 0.4198 \\
\hline 10 & 0.3673 & 0.6815 & 0.5492 & 0.8537 & 0.6706 & 0.8718 & 0.9 & 0.5452 & 0.1893 & 0.1 & 0.4525 & 0.4198 & 0.5249 \\
\hline 11 & 0.6815 & 0.5492 & 0.8537 & 0.6706 & 0.8718 & 0.9 & 0.5452 & 0.1893 & 0.1 & 0.4525 & 0.4198 & 0.5249 & 0.4164 \\
\hline 12 & 0.5492 & 0.8537 & 0.6706 & 0.8718 & 0.9 & 0.5452 & 0.1893 & 0.1 & 0.4525 & 0.4198 & 0.5249 & 0.4164 & 0.3237 \\
\hline
\end{tabular}

Tabel 4. Data Pengujian Jaringan

\begin{tabular}{|c|c|c|c|c|c|c|c|c|c|c|c|c|c|}
\hline \\
\hline pola & $\mathrm{x} 1$ & $x 2$ & $x 3$ & $x 4$ & $x 5$ & $x 6$ & $x 7$ & $x 8$ & $x 9$ & $\mathrm{x} 10$ & $\mathrm{x} 11$ & $\mathrm{x} 12$ & target \\
\hline 1 & 0.8537 & 0.6706 & 0.8718 & 0.9 & 0.5452 & 0.1893 & 0.1 & 0.4525 & 0.4198 & 0.5249 & 0.4164 & 0.3237 & 0.3079 \\
\hline 2 & 0.6706 & 0.8718 & 0.9 & 0.5452 & 0.1893 & 0.1 & 0.4525 & 0.4198 & 0.5249 & 0.4164 & 0.3237 & 0.3079 & 0.4155 \\
\hline 3 & 0.8718 & 0.9 & 0.5452 & 0.1893 & 0.1 & 0.4525 & 0.4198 & 0.5249 & 0.4164 & 0.3237 & 0.3079 & 0.4155 & 0.7197 \\
\hline 4 & 0.9 & 0.5452 & 0.1893 & 0.1 & 0.4525 & 0.4198 & 0.5249 & 0.4164 & 0.3237 & 0.3079 & 0.4155 & 0.7197 & 0.8078 \\
\hline 5 & 0.5452 & 0.1893 & 0.1 & 0.4525 & 0.4198 & 0.5249 & 0.4164 & 0.3237 & 0.3079 & 0.4155 & 0.7197 & 0.8078 & 0.1 \\
\hline 6 & 1893 & 0.1 & 0.4525 & 0.4198 & 0.5249 & 0.4164 & 0.3237 & 0.3079 & 0.4155 & 0.7197 & 0.8078 & 0.1 & 0.2086 \\
\hline 7 & 0.1 & 0.4525 & 0.4198 & 0.5249 & 0.4164 & .3237 & 0.3079 & 0.4155 & 0.7197 & 8078 & 0.1 & .2086 & .1748 \\
\hline 8 & 0.4525 & 0.4198 & 0.5249 & 0.4164 & 0.3237 & 0.3079 & 0.4155 & 0.7197 & 0.8078 & 0.1 & 0.2086 & 0.1748 & 0.1205 \\
\hline 9 & 0.4198 & 0.5249 & 0.4164 & 0.3237 & 0.3079 & 0.4155 & 0.7197 & 0.8078 & 0.1 & 0.2086 & 0.1748 & 0.1205 & 0.1082 \\
\hline 10 & 0.5249 & 0.4164 & 0.3237 & 0.3079 & 0.4155 & 0.7197 & 0.8078 & 0.1 & 0.2086 & 0.1748 & 0.1205 & 0.1082 & 0.1983 \\
\hline 11 & 0.4164 & 0.3237 & 0.3079 & 0.4155 & 0.7197 & 0.8078 & 0.1 & 0.2086 & 0.1748 & 0.1205 & 0.1082 & 0.1983 & 0.6286 \\
\hline 12 & 0.3237 & 0.3079 & 0.4155 & 0.7197 & 0.8078 & 0.1 & 0.2086 & 0.1748 & 0.1205 & 0.1082 & 0.1983 & 0.6286 & 0.9 \\
\hline
\end{tabular}

Data pelatihan dan pengujian jaringan yang telah disiapkan pada Tabel 3 dan 4 untuk pengolahan kedalam software Matlab, dilakukan pemrograman untuk melakukan pelatihan jaringan. Menggunakan arsitektur jaringan saraf 12-10-1, terdiri dari 12 nilai masukan data curah hujan selama satu tahun atau 12 bulan, 10 neuron pada hidden layer, dan 1 nilai keluaran data curah hujan pada bulan berikutnya ditampilkan pada Gambar 3.

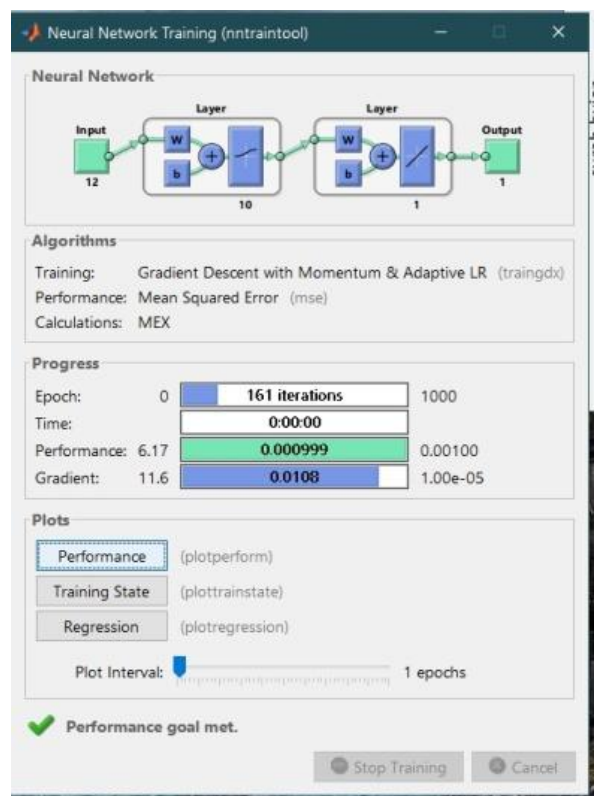

Gambar 3. Pelatihan Jaringan dengan Matlab 
Pada tahap pelatihan error goal atau MSE sebesar 0.00099899 dicapai pada epoch yang ke 161 seperti pada Gambar 4.

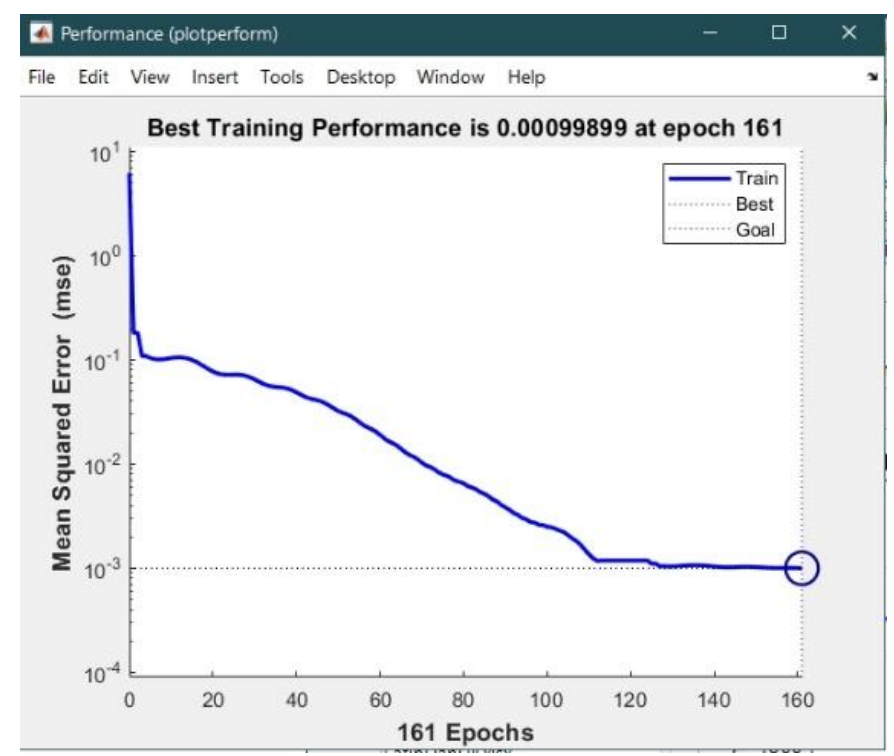

Gambar 4. Training Performance

Koefisien korelasi R yang dihasilkan adalah sebesar 0.99205, ditampilkan pada Gambar 5.

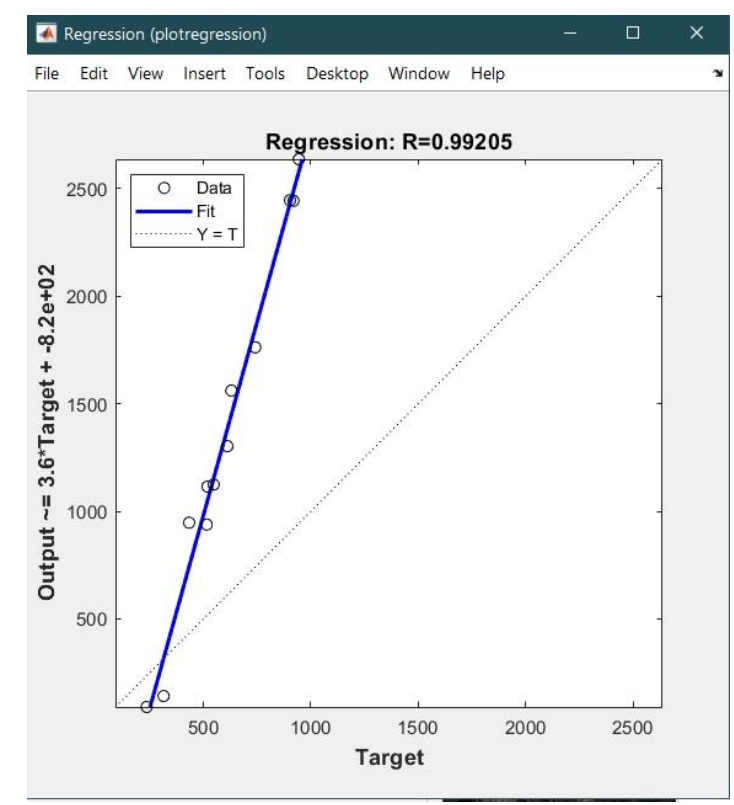

Gambar 5. Koefisien relasi

Hasil perbandingan keluaran jaringan saraf tiruan prediksi curah hujan dengan target data curah hujan sebenarnya seperti pada Gambar 6 . 


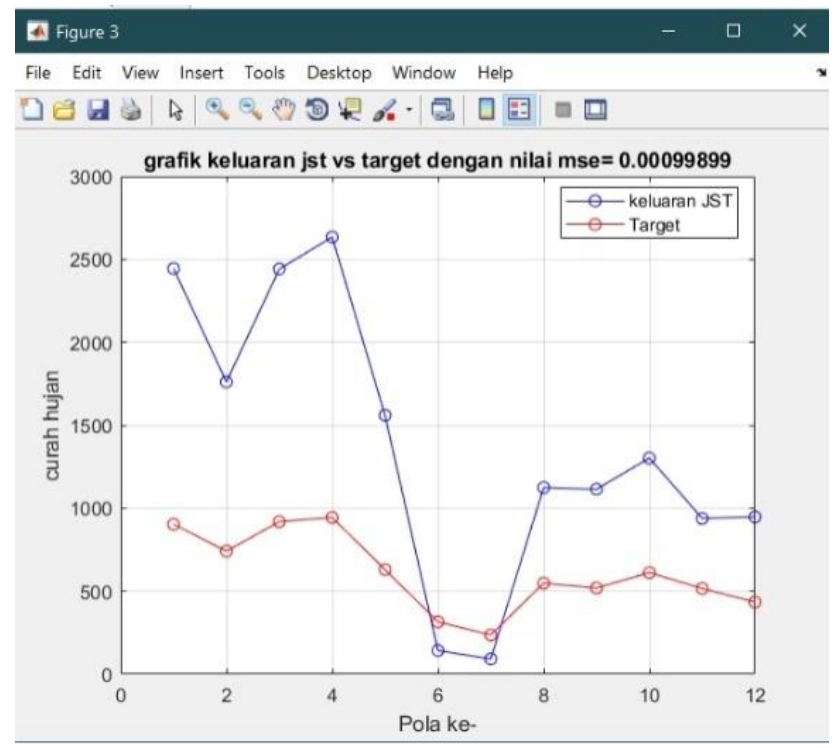

Gambar 6. Hasil perbandingan

Berdasarkan nilai koefisien korelasi dan nilai mean square error yang diperoleh pada proses pelatihan tersebut, jaringan saraf tiruan dapat memprediksi curah hujan, pada tahap pengujian jaringan nilai MSE yang dihasilkan pada proses pengujian menunjukkan bahwa jaringan saraf tiruan backpropagation cukup baik memprediksi curah hujan, performasi jaringan dapat ditingkatkan performasinya dengan memperbanyak data latih serta mengubah parameter yang memperngaruhi performasi seperti error goal, jumlah epoch, arsitektur jaringan serta jenis fungsi aktivasi. MSE yang diperoleh pada pengujian jaringan dengan nilai 0.17042, ditampilkan pada Gambar 7.

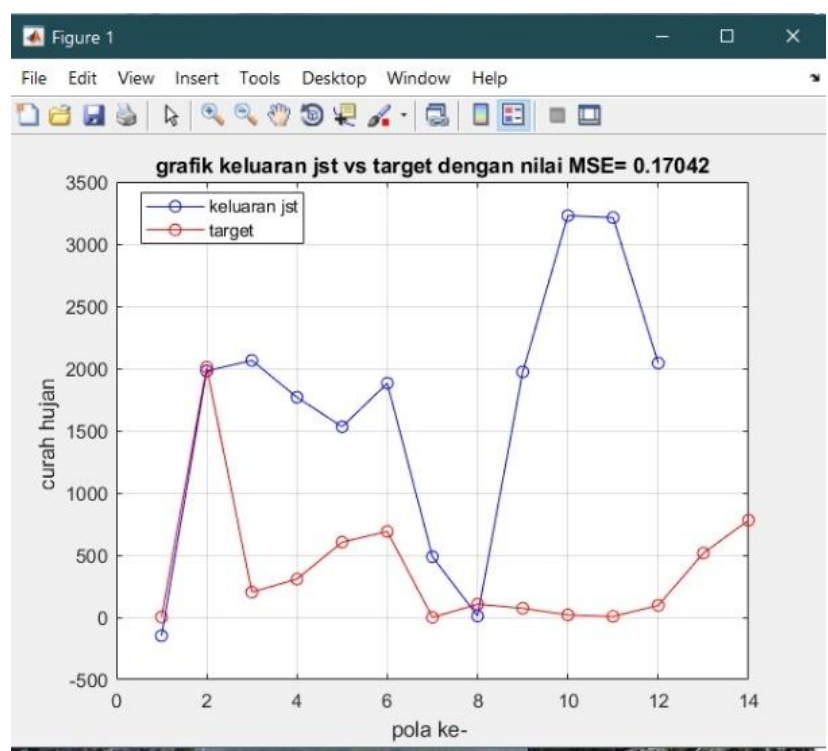

Gambar 7. Pengujian Jaringan 


\section{SIMPULAN}

Dari penelitian ini didapatkan kesimpulan yaitu semakin banyak jumlah lapisan tersembunyi pada suatu jaringan tiruan maka semakin bagus hasil prediksi yang dihasilkan, pada pengujian dengan lapisan 10 tersembunyi memiliki akurasi yang cukup baik untuk peramalan curah hujan, jumlah lapisan tersembunyi yang berbeda jumlah iterasi juga berbeda, jumlah lapisan tersembunyi yang lebih besar tidak selalu menyebabkan iterasi meningkat, peningkatan performasi jaringan dengan memperbanyak data latih dan mengubah parameter yang mempengaruhi performasi, seperti jumlah epoch, error goal serta arsitektur jaringan.

\section{DAFTAR PUSTAKA}

BMKG. (2010). Kondisi Cuaca Ekstrem dan Iklim Tahun 2010-2011. Jakarta. Retrieved from http://data.bmkg.go.id/Share/Dokumen/press release kondisi cuaca ekstrim dan iklim tahun 2010-2011.pdf

Dewi, K. N. A., Bahri, S., \& Irwansyah. (2015). Model Prediksi Curah Hujan Harian Menggunakan Jaringan Syaraf Tiruan Backpropagation. Eigen Mathematics Journal, 1-5.

Haviluddin, Arifin, Z., Kridalaksana, A. H., \& Cahyadi, D. (2016). Prediksi Kedatangan Turis Asing ke Indonesia Menggunakan Backpropagation Neural Networks. Jurnal Teknologi Dan Sistem Komputer, 4(4), 485-490. https://doi.org/10.14710/jtsiskom.4.4.2016.485-490

Manalu, M. T. P. (2016). Jaringan Syaraf Tiruan untuk Memprediksi Curah Hujan Sumatera Utara dengan Metode Backpropagation(studi kasus:BMKG Medan). Jurnal Riset Komputer, 3(1), 35-40.

Mukid, M. A., \& Sugito. (2013). Model Prediksi Curah Hujan Dengan Pendekatan Regresi Proses Gaussian. Universitas Diponegoro, 6, 113-122.

Oktavianingsih, I., Muliadi, \& Apriyansyah. (2018). Estimasi Curah Hujan di

Kota Pontianak Menggunakan Metode Propagasi Balik Berdasarkan Parameter Cuaca dan Suhu Permukaan Laut. Prisma Fisika, VI(2), 89-93.

Pradnyana, I. P. B. A., Soebroto, A. A., \& Perdana, R. S. (2018). Peramalan Curah Hujan Menggunakan Metode Jaringan Syaraf Tiruan Dengan Optimasi Algoritma Bee Colony. Jurnal Pengembangan Teknologi Informasi Dan Ilmu Komputer, 2(February), 3624-3631.

Rachmawati, A. (2015). Prediksi Curah Hujan Di Kota Pontianak Menggunakan Parameter Cuaca Sebagai Prediktor Pada Skala Bulanan, Dasarian dan Harian. Positron, V(2), 50-57.

Sutawinaya, I. P., Astawa, I. N. G. A., \& Hariyanti, N. K. D. (2017). Perbandingan Metode Jaringan Saraf Tiruan Pada Peramalan Curah Hujan. Jurnal Logic, 17(2), 92-97.

Wonosobokab.go.id. (2014a). Geografis Kabupaten Wonosobo. Retrieved June 14, 2019, from https://wonosobokab.go.id/website/index.php/2014-02-0104-40-52/selayang-pandang/geografis-kabupaten-wonosobo 
Wonosobokab.go.id. (2014b). Potensi Daerah Kabupaten Wonosobo. Retrieved from https://wonosobokab.go.id/website/index.php/rpjmd/itemlist/ category/10-potensi-daerah

Yunita. (2015). Prediksi Cuaca Menggunakan Metode Neural Network. Paradigma, XVII(2), 47-53. 